\title{
WHO ARE THE GENTRIFIERS AND HOW DO THEY CHANGE CENTRAL CITY NEIGHBOURHOODS? PRIVATIZATION, COMMODIFICATION, AND GENTRIFICATION IN BUCHAREST
}

\begin{abstract}
CHELCEA, L., POPESCU, R., CRISTEA, D. (2015): Who Are the Gentrifiers and How Do They Change Central City Neighbourhoods? Privatization, Commodification, and Gentrification in Bucharest. Geografie, 120, No. 2, pp. 113-133. - Our understanding of gentrification outside of the Anglo-Saxon core is relatively undeveloped. In order to contribute to a more de-centered approach, we ask who are the gentrifiers and how do they change central city neighbourhoods in a post-socialist context? The answers are explored through a mixed-methods approach, using both quantitative and qualitative data: construction permits analysis, census tract data, field trips, and interviews with tenants, former owners, and real estate agents. Findings indicate that gentrifiers vary in nature. They include state tenants, former owners, marginal gentrifiers, political capitalists, and institutional investors. Through their actions, central neighbourhoods have gained younger, more educated, and smaller households. Beyond this case study, we emphasize the usefulness of rent gap theories, the need to study displaced households, and the potential of property rights to enrich theories of gentrification.

KEY WORDS: gentrification - gentrifiers - Central City - Bucharest.
\end{abstract}

\section{Introduction}

One common analytical strategy in studies of gentrification is to follow its "global" emergence (Smith 2002; Atkinson, Bridge 2005). This strategy, however, has brought problems along with it, especially since such portable analytical strategies downplay local forms and variation (Kovacs 2013, van Gent 2012). Various studies have called for increased attention to the ways this process unfolds outside the Anglo-Saxon core. Atkinson and Bridge (2005, p. 3) call for "an expanded imagination and nuanced reading of the profile and contextual unraveling of the process". Similarly, Bernt and Holm (2005, p. 108) have called for gentrification research to be embedded "into a more advanced political economy of land and housing markets and an analysis of state intervention which has often been lost sight of". More recently, Lees, Shin and Lopez-Morales et al. (2015, p. 6) have suggested that "more than preserving and 'patrolling' the use of the 'gentrification' concept ... what is needed is proper global debate among scholars from South, North, West and East".

Following this research tradition, we ask two questions: (1) who are the gentrifiers (and how do they operate) in a post-socialist context? and (2) what are the aggregate social and spatial effects of their activities? In answering 
these questions, we emphasize that paying stronger analytical attention to the role of property rights transformation will be useful to understanding gentrification. The 1990s and 2000s were a period of intense housing property rights reform, changing state projects, and social dumping (Struyk 1996). After 1990 the housing stock in Eastern Europe and the former USSR changed hands, underwent rent deregulation, and experienced tenancy changes. This happened in a short period of time and on a scale unprecedented either in the region or elsewhere in the world. Increased attention to property rights might inform research on gentrification carried out outside the ex-socialist cities in meaningful ways, as different conceptions of property, entitlements, and institutional arrangements are crucial in changing geographies of urban inequalities in cities across the world.

References to the links between property rights and gentrification are present in several studies. Outside Europe, but also in a post-socialist context (Shanghai, China). He (2007, p. 186) indicates that, because of fragmented property rights and the mixed composition of housing tenure, "the traditional form of gentrification through spontaneous and piecemeal housing rehabilitation is rarely possible in China [... it] only takes place in the few cases where the property rights of old houses are clear". The theoretical potential for property rights transformations in post-socialist urban contexts has had an impact even outside urban studies. One legal scholar coined the widely used term "anti-commons", an analytical concept that emerged from efforts to understand property rights fragmentation and changes in old housing in Moscow in the 1990s (Heller 1998). Similarly, Sýkora (2005, p. 101), reviewing gentrification in four post-socialist cities, concluded that "two forms of housing privatization deserve particular attention: restitution and flat privatization that have created substantially different conditions for the mechanisms of neighborhood change".

In this context, the new element added by our study is the creation of a complex typology of housing commodification strategies, where gentrification is tied to property rights. We constructed this typology bearing in mind several studies of gentrification, housing, and neighborhood change in post-socialist cities (Pickvance 2002; Forrest, Murie 1995; Golubchikov, Badyina 2007; Bodnar 1996; Ruoppila 2004; Daniell, Struyk 1994; Haase et al. 2012; Sýkora 2005; Kovacs 1994; Kovacs 2013). We begin by presenting the methodology that we used. We continue with a section on who the gentrifiers are and how they operate. In the following section, we present the aggregate effects of their activities. We end with some conclusions that exceed our case study, locating our findings on the wider canvas of studies of gentrification, in the region and elsewhere.

\section{Research design, data and methods}

In analyzing gentrification, we used a mixed-methods approach (cf. Pattaroni et al. 2012; Brown-Saracino 2010, p. 359). The area that we analyzed covers Bucharest's central neighborhoods which lie inside the inner city "ring" (see Fig. 1). They account for about $20 \%$ of Bucharest's land area and are dominated by low-rise buildings, constructed in the $19^{\text {th }}$ and early $20^{\text {th }}$ centuries, some of 


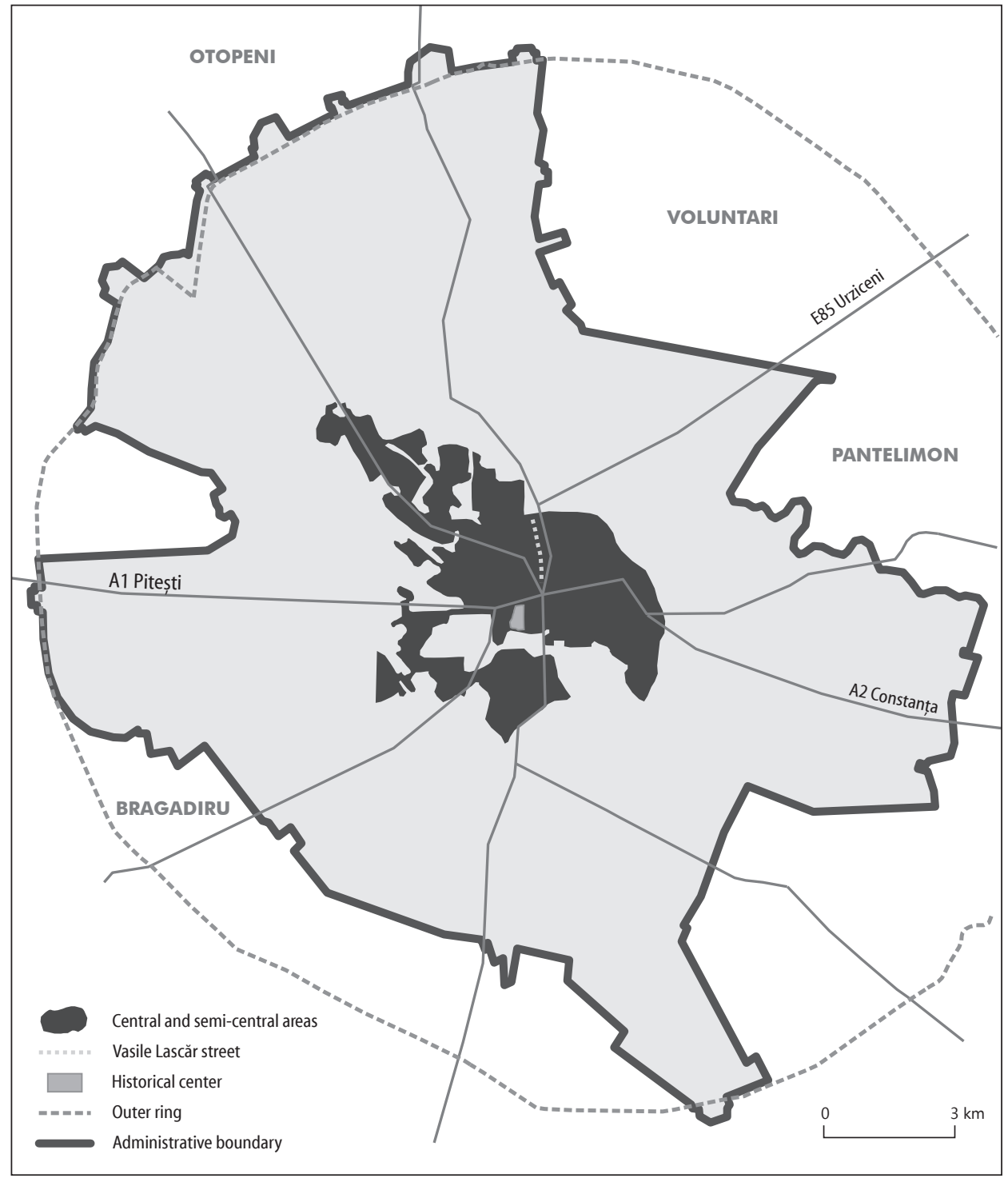

Fig. 1 - Map of Bucharest and the area analyzed

which are detached and surrounded by gardens, some contiguous. Bucharest is especially relevant for this issue of property rights and gentrification, as restitution has lingered and is still -25 years after the end of socialism - an issue on the public agenda.

In order to understand who the post-socialist gentrifiers are and how they operate, we carried out interviews with 41 real-estate agents, former owners, and tenants. We also practiced participant observation, through guided tours offered by real-estate agents to show us around housing, and non-participant 
observation through field trips. Some interactions were formal, semi-structured interviews, some were casual on-site conversations. The issues were delicate, as some aspects were shady, and some outright illegal. Although we feel that we obtained good data, one limitation is that we cannot offer the quantitative distribution of such strategies.

In order to ascertain what the aggregate effects of gentrifiers' operations in central areas are, we used several research techniques, mainly quantitative, but also qualitative. We present and discuss the data in relation to three analytical components: investments, household composition, and cultural attractiveness (Bernt, Holm 2005). For each component we used different methods and data. To understand real-estate investments, we compiled a database of construction permits issued between 1990 and 2012 in our area. Out of all the permits issued during this period in Bucharest, we selected those that belonged to our census tracts, and then recoded them. Using simple, descriptive statistics from 1992, 2002, and 2011 census-tract data, we analyzed social composition. We did not have access to microdata, but rather to aggregate, census-tract data for age, education, housing surface, profession and household size. We lumped together the historical center and semi-central areas, in order to get the aggregate level dynamics. This has the advantage of avoiding the problem of census-tract boundaries (they changed slightly for each census). Finally, for understanding changes in cultural attractiveness, we used field observation in selected areas and secondary analysis of the entertainment and gastronomic scene. Lumping together relatively large areas of the central city runs the risk of flattening out the geographies of neighborhood gentrification. In order to correct this, we included two case studies of neighborhood change, especially since our findings indicate the patchy nature of the gentrification. One covers the actual Historic Center; the other, a semi-central neighborhood based around Vasile Lascăr Street.

Although cases studies of gentrification present both strengths and weaknesses (see Hackworth, Smith 2001, p. 639), they are the backbone of the long tradition of gentrification research. Starting with iconic studies of East London, 1980s Lower Manhattan (Zukin 1982), and the Lower East Side (Smith, Defilippis 1999), all the way to more recent studies, including those of post-socialist cities, case studies dominate the study of gentrification. Occasionally, the analytical effort is focused on more than one neighborhood within one city (Hackworth, Smith 2001; Pattaroni et al. 2012), and sometimes on comparisons between cities (Bernt 2012; Nagy, Timár 2012). Studies using larger number of cases, based on inferential statistics and hypothesis testing, are a rare exception (Wyly, Hammel 2005). We did not set out to carry out a study of segregation, but rather to understand the actors of gentrification and the change in central neighborhoods.

\section{Who are the gentrifiers and how do they operate? Six commodification strategies}

Below, we will describe the link between privatization, commodification, and gentrification as it materialized in six emblematic trajectories and strategies. Various actors facilitated privatization and subsequently pushed for 
commodification and displacement in order to close the rent gap. Before we present them, we need to stress two elements about housing in Bucharest. One is legislative and contextual. In 1991 most state-owned housing was privatized. From the mid-1990s, the issue of legal disputes over housing restitution came to the fore and, in different ways and with varying intensities, it has remained important up to the present day. As a rule, sitting tenants were allowed to purchase "their" houses and the land beneath them, provided that the former owners did not seek restitution in court. Old and well-located houses were sold for about $10 \%$ of the market value, irrespective of location, architectural value, or soundness (Stan 2013, Dawidson 2004).

The second point is conceptual. By themselves, neither the privatization nor the restitution of housing have created full bundles of private property rights, but rather limited commodification. As Forrest and Murie (1995) remind us, privatization and commodification are conflated in many cases (see also Ronald 2012). Privatization (and restitution) legislation do not necessarily promote entrance into the real-estate market (ibid. 1995, p. 408). For the former owners who won their houses back from local councils, commodification occurred informally and sometimes illegally during the 1990s. State concerns with risks and the tenants' political lobby materialized in legal limits on commodification. Since 1995 the state has legislated protection against eviction for 10 years, banned the alienation of acquired houses by sitting tenants, and imposed "rent caps"1 (Bernt 2012, p. 3056). The huge rent gap between the low privatization prices and "rent caps" on the one hand and the value of centrally located housing on the other, created substantial pressure to escape rent regulations. This stimulated the creativity of sitting tenants, tenants turned into owners, former owners, and real estate agents to deploy formal, informal, legal, and illegal strategies for commodification and displacement. What were these strategies and how did they play out in producing commodifiable and gentrifiable housing?

One strategy used to appropriate state housing was providing false loans to financially disadvantaged tenants, who did not have the resources, but had the right to privatize state housing and then seek commodification through displacement. Serendipitous real estate agents identified such tenants and offered them the initial funds to buy the apartments from the state, under the provision that the creditors would eventually acquire the ownership rights. As the legislation prohibited the selling and commodification of these buildings, the parties practiced a juridical artifice. Agents masked the entire deal as a loan to the tenants. Tenants offered their newly acquired houses as "collateral". Tenants did not repay, and real-estate agents assumed ownership. The latter then purchased cheaper apartments in high-rise buildings in the socialist-era areas of Bucharest on behalf of the ex-tenants. The former ended up owning cheaper apartments in non-premium areas, while the real-estate agents acquired premium properties which were then renovated, rented, or resold. Such "sale" of tenancies, although carried out in connection with privatization and commodification after 1990, is not a new process, but rather a continuation of socialist-era practices (Pickvance 1994, p. 435; Ruoppila 2004, p. 15; Daniell, Struyk 1994, p. 512; Bernt 2012, p. 3056).

1 The maximum rent topped $25 \%$ of the tenants' household' income. 
The second displacement strategy affecting socialist-era tenants was linked to housing restitution. Since the mid-1990s many former owners have managed to obtain a restitution decision in court. Some acted independently, but, especially after 2000 , there were consistent reports, as well as some court verdicts (sometimes in horrible corruption cases), that indicated the emergence of groups composed of former owners, lawyers, and local administration employees who were speeding up the restitution process. Such groups received restitution decisions much more easily than other people, thus preventing sitting tenants from purchasing housing of this type. In such cases, the departure of tenants took place quickly, reinforcing the observation that "tenants living in restitute housing are vulnerable to displacement" and that "this housing segment is most likely to be further gentrified" (Sýkora 2005, p. 88). One legally prescribed way out of this situation was to provide substitute housing for the tenants. As in the first strategy, many owners relocated their tenants to other apartments purchased in less expensive areas, before renovating, renting, and selling the buildings. We do not have figures on how often this happened, but as a rule such relocations were resented and resisted by tenants.

The third strategy is similar to the first two, in the sense that central location is capitalized through relocation, this time by tenants themselves. The "voluntary" self-relocation of sitting tenants to other parts of the city after privatization may be described as a transition from owner occupancy to renting. As Daniell and Struyk (1994, p. 511) noticed, some "privatize[d] to acquire a valuable asset with the potential of providing rental income". Sýkora also describes (2005, p. 102) how "[tenants'] voluntary displacement while leaving the inner city provided them with an opportunity to capitalize the rent gap for their own pockets". Senior citizens sometimes practiced this, moving to live with their children in other parts of the city. After vacating their housing, they rented it on the market. Although there was legislation prohibiting this, one occasionally learned of such profitable subleases by tenants who thereby bypassed the "rent-caps".

Three other strategies leading to relocation involve, like the previous one, sitting tenants as gentrifiers. In Romania, perhaps more than in other postsocialist countries, many politically upwardly mobile people were able to obtain advantageous tenancy contracts, enabling them later on to purchase the housing units that they occupied. Local and national politicians, municipal administration employees, members of parliament and even the ex-president (Traian Băsescu) acquired valuable housing at ridiculously low prices. Such gentrifiers may be called, using Katherine Verdery's term, "super-tenants", that is, persons who obtained state houses for very little money despite of their financial means, which would have allow them to purchase it, rather than to be granted it. Upward redistribution of houses went hand in hand with privatization during the 1990 s. In some cases, such politically powerful

2 Anthropologist Katherine Verdery (2003, also 2003, p. 152) used this term to designate persons who rent land from the newly created owners of small lots in the countryside, but who are financially much better off because they control agricultural equipment and relations with the economic and political centers outside villages. The meaning of the concept may be adapted to urban tenancy relations as well. 
tenants lived in the same building with financially disadvantaged tenants. Such situations occurred when poorer tenants were allocated under socialism parts of nationalized buildings that were initially designed as basements, storage spaces or outbuildings. The super-tenant families occupied the main apartment, while poorer tenants inhabited the marginal spaces. The former tried, and in some cases succeeded, in influencing the state office that runs these houses to relocate the poor tenants to other housing units. Super-tenants ask for extensions of their lease to cover vacated spaces, thus placing themselves in a position to purchase the entire building.

The fifth pathway, often used by tenants after privatization, is to treat their newly acquired houses as a frontier of profitability, through their expansion into previously unclaimed parts of their buildings - mainly attics, but also basements. This meant their functional conversion from storage to residential use through small financial investments (Soaita 2012, Soaita 2013). A good illustration is a two-level, detached house, shared by three families, who were fortunate enough to purchase the building in 1998 before the former owners reclaimed it. The family who occupied the upper level and controlled the entrance to the 98-square-meter attic sought to appropriate the attic too. After petitioning the state housing office in 2000 , they received an expansion of the tenancy contract. They were approved the same year. After that, they cleaned up the space and begun enclosing it into separate rooms, in order to create two studios. They only had money for one, however, thus creating a bathroom, a kitchen, and a bedroom out of half the attic. Then they rented it through a real estate agency. This strategy is relatively common because many buildings, especially those built around the turn of the twentieth century need repair. Upon repair, ex-tenant families turn such additional spaces into money-making spaces, by modifying and expanding the layout and volume of attics. Perhaps this comes closest to the classic form of gentrification with landlords hiring builders to repair their houses.

Finally, the last trajectory to gentrification was care-for-inheritance exchanges, or informal reverse mortgage payments, a strategy noted by Daniell and Struyk (1994, pp. 511, 523) during privatization. As senior, single households are overrepresented in Bucharest's central areas, younger families adopt quasikinship relations with older, disadvantaged sitting tenants. Such residents are helped by neighbors or acquaintances out of a combination of calculated generosity and pity. The underlying agreement is that the supporting family will inherit the apartment upon the death of senior citizen. In one area that we knew quite well, the Orthodox parish acted as a middleman for old people and younger families, helping find appropriate matches. This situation is more general, in the sense that privatization of housing was imagined by the elderly as a capital easily convertible into care (see Ronald, Elsinga 2012).

All these strategies gradually produced, during the 1990 s and 2000 s, commodified freehold housing, allocated by the market rather than the state. They shed light on who were the agents of gentrification and displacement, and how freehold housing was "produced" for those who could afford to pay unregulated rents. Some were marginal gentrifiers (Rose 1989), others were well-placed public servants or "political capitalists" actively "making capitalism without capitalists" (Staniszkis 1991; Eyal, Szelenyi, Townsley 1998; Stoica 2004) - in 
other words, beneficiaries of the socialist and early post-socialist era redistributive housing policies. They stand in rather stark contrast to the agents of the third wave of gentrification of the mid 2000 s, who tended to be investment companies, rather occasional real-estate agents.

\section{How do gentrifiers change the central city neighbourhoods? Investments, household composition and cultural attractiveness in central Bucharest}

We present next the answer to the second research question. Let us start with data on investments. During the 1990 s, investments were limited to the investments of sitting tenants, tenants turned into owners, and former owners. Investments by real estate companies in the old housing stock were very limited. Investments were few and based on self-provision, as the housing provision in Romania is generally family-based (Mandic 2012; Urse, Popescu 2009).

Since 2005, however, close to the top of real estate bubble in Romania, market allocation and the lifting of commodification barriers became more widespread. The 10-year ban on the selling of houses privatized to sitting tenants expired. Many tenants began selling their houses at market prices. The period of commodification overlapped with a cycle of substantial growth in real estate investment in Bucharest. Real estate investments in Romania grew from 300 million Euros in 2004 to 1.6 billion four years later (Collier International 2012, p. 5). Most investments were concentrated in Bucharest and were focused on office buildings, malls, shopping centers, high-rise gated communities, erected usually on land formerly occupied by industrial plants, and, occasionally, luxury condos in the central areas.

This led to the construction of in-fills on valuable land obtained from demolishing older houses, here and there. The real estate boom meant mainly a wave of evictions, demolitions and new-built residential gentrification, arguably an instance of third-wave gentrification (Davidson, Lees 2005). Banks began to lend construction and mortgage loans. Whereas the early gentrifiers described in the previous section did not have substantial amounts to invest and could not use the land, the boom period witnessed the arrival of investment funds from Austria, Israel, the UK, and Spain. The number of new buildings in central areas almost doubled from about 1000 in 2002 to about 1800 in 2006, whereas their average surface area increased about six times from about 250 square meters to about 1,500 square meters in 2008 , indicating a much more intensive usage of land. ${ }^{3}$

A good illustration is this aerial photo of a very expensive area of Bucharest developed around Eminescu street (see Fig. 2). One may notice the low-rise landscape of this area. The plots marked " $D$ " are obtained by demolishing old houses after the eviction of the tenants. As of 2012, no fewer than four such plots can be identified. The 10 buildings marked "C" are high-rise condos already constructed on similar plots. They target rich mortgage-taker families. Their price averaged 300,000 Euros/apartment prior to the global financial crisis.

3 National Statistics Institute, Tempo survey, 2002-8. 
Table 1 - Construction permits in Bucharest's central areas, 1990-2012, by categories

\begin{tabular}{|lrr|}
\hline Construction permits & $\mathrm{N}$ & Percent \\
\hline New Constructions & 133 & 10.30 \\
Structural works & 169 & 13.10 \\
Demolition & 200 & 15.50 \\
Re-functionalization & 104 & 8.00 \\
Expansion and re-compartmentalization & 230 & 17.80 \\
Repairs and interior design & 277 & 21.40 \\
Connectivity to urban infrastructures, & 31 & 2.40 \\
energy retro-fitting, insulation etc. & 102 & 7.90 \\
Accessibility and auxiliary (technical) constructions & 46 & 3.60 \\
Others & 1,292 & 100.00 \\
\hline Total & & \\
\hline
\end{tabular}

Construction permits may also shed light on investments. Our statistical analysis indicates that most construction permits were granted for repairs, extensions, and re-compartmentalization. Altogether these account for $40 \%$ of the total (see Table 1). This makes sense, since many of the central areas have heritage status and landlords are not allowed to demolish rent-controlled dwellings. "Violent" interventions - demolition and residentialization - account for about $25 \%$ of all construction permits. The rest consists of re-compartmentalization, improvements to urban infrastructures, consolidation, addition and elimination of auxiliary buildings, interior design, fences, and so on. Gentrification was, therefore, improvement-based, through altering, enlarging and refurbishing the existing housing stock, along with some new-built residentialization.

Repairs, interior design, extensions and re-compartmentalization, as well as structural works predominated, adding up to $70 \%$ of all permits in the post-2002 period. This is a threefold increase compared to the pre-2002 figures,

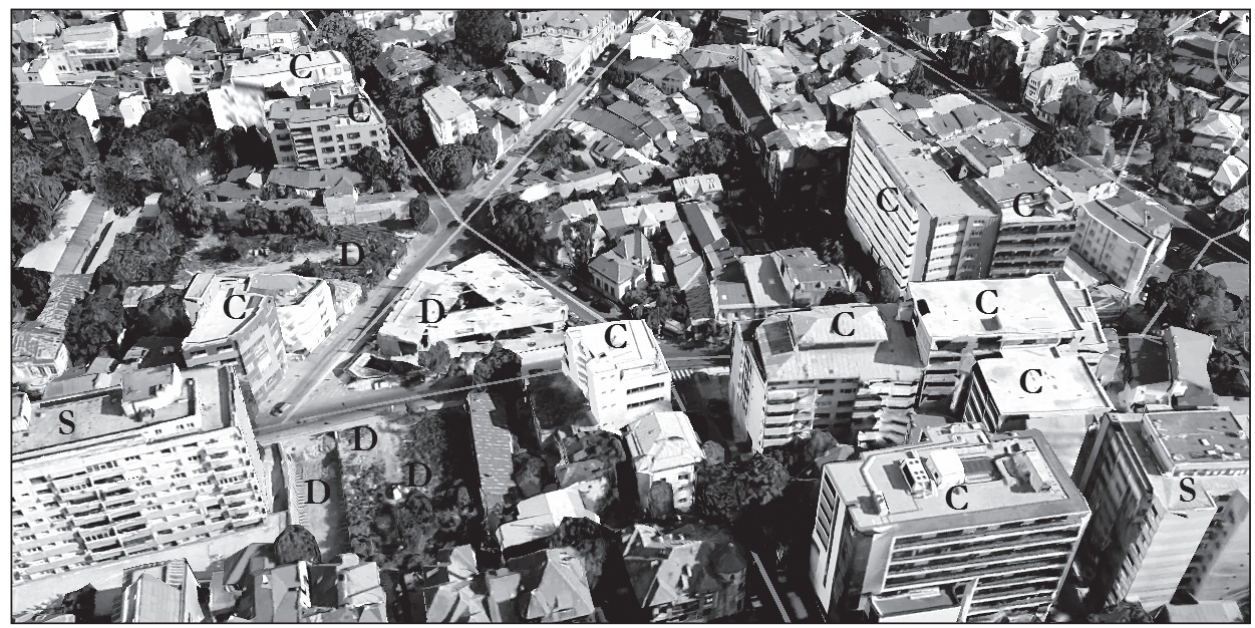

Fig. 2 - Aerial view of Eminescu Street area: D - demolished, C - condos, S - socialist era condos 
which may be read as increased commercialization, i.e. the "growth in the share of non-residential uses in the city" (Sýkora 2005, p. 95), a process common in many centrally located neighborhoods undergoing gentrification.

Although the general data indicate that Bucharest - like other post-socialist cities - entered the second demographic transition (Haase et al. 2012), the central areas seem to have evolved in the opposite direction, as their population is getting younger. The percentage of the population aged $0-19$ is almost at the same level in the city center as for the rest of Bucharest. The percentage of older people has decreased in central areas, whereas it has increased for the city as a whole. The central areas have gained young adults and middle youth at a higher pace than the rest of the city. Similarly the gap between the center and the rest of the city for the percentage of seniors is $3 \%$, as opposed to the $6 \%$ of 1992 or 2002 (Table 2).

The figures on occupancy, density and average surface per dwelling also offer some interesting insights (see Table 3). One may notice the continuation of the historical tendency of diminishing density in central areas (Chelcea 2012). The number of persons per housing unit decreased by $13 \%$ between 1992 and 2011 , faster than in the rest of Bucharest. This reflects the relocation of ex-tenants to other parts of the city through the strategies mentioned above. This trend is noticeable as one walks around in the central areas. Many restituted buildings were abandoned by their owners, after the tenants were evicted. The "underoccupation" of central housing is even more pronounced in terms of occupancy

Table 2 - Population of the central areas in 1992 to 2011, by age

\begin{tabular}{|c|c|c|c|c|c|c|}
\hline \multirow[b]{2}{*}{ Age } & \multicolumn{2}{|c|}{1992} & \multicolumn{2}{|c|}{2002} & \multicolumn{2}{|c|}{2011} \\
\hline & Bucharest & Center & Bucharest & Center & Bucharest & Center \\
\hline $0-19$ & 27.59 & 22.01 & 19.73 & 17.86 & 16.40 & 15.35 \\
\hline $20-44$ & 39.88 & 34.53 & 41.18 & 36.49 & 43.50 & 40.85 \\
\hline $45-64$ & 21.26 & 24.35 & 25.34 & 25.13 & 25.65 & 26.06 \\
\hline 65 and over & 11.27 & 19.12 & 13.75 & 20.52 & 14.45 & 17.74 \\
\hline
\end{tabular}

Source: National Statistics Institute, 1992, 2002, 2011 census data, personal calculation.

Table 3 - Occupancy rates (housing units and rooms), average surface per person and surface of rooms

\begin{tabular}{|c|c|c|c|c|c|c|}
\hline & \multicolumn{2}{|c|}{1992} & \multicolumn{2}{|c|}{2002} & \multicolumn{2}{|c|}{2011} \\
\hline & Bucharest & Center & Bucharest & Center & Bucharest & Center \\
\hline $\begin{array}{l}\text { Occupancy rate } \\
\text { (housing units) }\end{array}$ & 0.96 & 0.96 & 0.91 & 0.85 & 0.89 & 0.83 \\
\hline $\begin{array}{l}\text { Occupancy rate } \\
\text { (rooms) }\end{array}$ & 1.11 & 0.97 & 1.00 & 0.81 & 0.91 & 0.76 \\
\hline $\begin{array}{l}\text { Surface per per- } \\
\text { son (sq meters) }\end{array}$ & 13.01 & 16.91 & 15.83 & 23.42 & 20.97 & 28.62 \\
\hline $\begin{array}{l}\text { Average surface } \\
\text { of rooms }\end{array}$ & 14.45 & 16.31 & 15.81 & 18.83 & 19.03 & 21.63 \\
\hline
\end{tabular}

Source: National Statistics Institute, 1992, 2002, 2011 census data, personal calculation. 
Table 4 - Education of residents in Bucharest and its centre

\begin{tabular}{|c|c|c|c|c|c|c|}
\hline & \multicolumn{2}{|c|}{1992} & \multicolumn{2}{|c|}{2002} & \multicolumn{2}{|c|}{2011} \\
\hline & Bucharest & Center & Bucharest & Center & Bucharest & Center \\
\hline Higher & 14 & 19 & 30 & 36 & 33 & 46 \\
\hline Secondary & 69 & 67 & 56 & 52 & 59 & 47 \\
\hline Primary & 15 & 12 & 12 & 10 & 7 & 6 \\
\hline No education & 2 & 2 & 2 & 2 & 1 & 1 \\
\hline
\end{tabular}

Source: National Statistics Institute, 1992, 2002, 2011 census data, personal calculation.

of rooms, which indicates that residents of central neighborhoods have more rooms and a higher surface area available than the rest of the city.

The data on education and workforce structure also indicate some changes (Table 4). The percentage of highly educated residents has increased at a much higher pace in the center than in the rest of Bucharest between 1992 and 2011. The number of individuals with secondary, little or no education has decreased. One could thus say that working-class and non-managerial service sector individuals have moved away from the city and especially from the city center. The breakdown on the economic sectors work is also revealing. Bucharest's economy is tertiarized, with 4 out 5 residents working in the service economy. Banking employees increased almost 3.76 times between 1992 and 2011 in the city, as did the number of IT\&C employees. The number of employees in public administration and commerce increased, whereas the number of those in manufacturing, and also of health and education personnel, decreased. The city center generally follows the figures for Bucharest as a whole, apart from IT\&C workers who tend to cluster in the center.

Overall, the analysis of household composition thus indicates some continuities, but also some discontinuities between the socialist era and the postsocialist period. There is a consistent literature indicating a stability in the levels of social segregation of post-socialist cities (Borén, Gentile 2007; Gentile, Tammaru, van Kempen 2012; Marcińczak 2012; Marcińczak, Musterd, Stępniak 2012). Despite intense change of hands over central housing (Chelcea 2006), our data indicate constant levels of change, in the sense that the socialist-era patterns of segregation remained present after 1989 (Marcińczak et al. 2014), but the distance between the center and the rest increased.

The third dimension of gentrification is cultural attractiveness. The central neighborhoods are dotted with many restaurants - featuring "Italian" cuisine, but also "Romanian" and other "ethnic" foods - public and private theaters, and cultural centers. There are also many tea houses, coffee shops, bars, pubs, and lounges catering for the youth population. We will illustrate some cultural changes by "zooming in" on two neighborhoods. As we will briefly describe below, many cultural ingredients of gentrification are present here: new foodscapes, slow-time spaces, commercial outlets for bohemian consumers, hand-made boutiques, and the commercialization of residential space. We describe two such neighborhoods below.

The area that has changed most visibly is the Historical Center. Its residential, commercial and repair services functions were changed in the late $2000 \mathrm{~s}$ 
to those of a major entertainment area. Despite its uninterrupted heritage attractiveness, 2007-2008 represented a rupture in terms of cultural dynamics. The Historical Center, following the rehabilitation of its water and gas infrastructure, the ban on cars, as well as the mass and forced eviction of underclass households around 2007 rapidly became a tourist and entertainment area (Berescu 2011). It has currently the highest density of pubs, restaurants, boutiques in the city, outlining a commercialization tsunami. Sipetean (2010) notes that the late 2000s reversed the 1980s pattern of abandonment, commercial decay, and concentration of poverty (including Roma households). Although almost 30\% of storefront properties were still abandoned as of 2010, the statistics indicate a substantial incoming of commercial investments, with no less than 110 coffee shops, restaurants, and pubs, and additional boutiques and retail spaces (see Table 5). Two years later, their number had increased to 160 (Totelecan 2015 , p. 9). Such statistics, as would a routine walk through the Historical Center, indicate a continuation of these trends, with no less than 29 properties being refurbished as of 2010 (Sipetean 2010) and some more later. In 2015 a major boutique bookstore (Cărtureşti) opened up in a landmark $19^{\text {th }}$ century building (a three-story bank with atrium).

The fact that some of the buildings were tenant-free inspired the owners to refurbish them. Some in-fills occurred on vacant lots, including a hotel. The Ministry of Culture together with local government began rehabilitating the $18^{\text {th }}$-century Hanul Gabroveni Inn, planning to turn it into a cultural center. Other landmarks - Hanul lui Manuc Inn and the restaurant Carul cu Bere were returned to their former owners and quickly became tourist destinations. The area now houses many restaurants, coffee shops, open-air pubs, as well as concert halls, whose density is now comparable to any touristic historical center in major European cities. Pro-heritage and conservationist voices have also become stronger (Tudora, Culescu 2011).

The neighborhood around Vasile Lascăr street (henceforth VLS) is another good example of the new foodscapes, urban rhythm, and commercialization taking place in central and semi-central areas. In the late $19^{\text {th }}$ century, this old street became dominated by tram transportation uniting the city center with the working-class neighbourhoods of the north-eastern parts of Bucharest. The street has three segments. The most central segment has mainly multi-storey buildings, which housed well-to-do families before, during, and after socialism. The second segment has single- or two-level buildings and is delimited by the two large boulevards created in the late $19^{\text {th }}$ century. The outer edge of this second segment has maintained to this day its commercial hub function, developed around Gemeni peasant market. Finally, the third segment of the street has historically been more working class, and included some Roma families. The houses are rarely higher than one level, and are smaller and less ornate then those of the first two segments. Overall, until the early 2000 s, the entire street was quiet by Bucharest's standards, prompting its inhabitants to call it a "God forsaken area".

Well into the early 2000 s, the street kept its presocialist and socialist aspect in terms of buildings, urban infrastructures, and rhythm. The infrastructures remained unchanged, while the houses, many of which had been nationalized, remained under-repaired especially after the 1977 earthquake (Rufat 2011). 
Table 5 - The structure of front store properties usage in the Historical Center, in 2010

\begin{tabular}{|lcc|}
\hline & Number & Percentage \\
\hline Abandoned spaces & 168 & 29 \\
Coffee shops, restaurants, pubs & 110 & 19 \\
Boutique clothing & 46 & 8 \\
Art, interior design, furniture, used books & 37 & 6 \\
Under construction & 29 & 5 \\
Public institutions & 23 & 4 \\
Wedding dresses & 17 & 3 \\
Tourism agencies and hotels & 17 & 3 \\
Textiles and tailoring & 12 & 2 \\
Shoes & 12 & 2 \\
Minimarkets & 12 & 2 \\
Bank offices & 12 & 2 \\
Medical supplies & 6 & 1 \\
Glassware & 6 & 1 \\
Copy-centers & 6 & 1 \\
Prezel shops & 6 & 1 \\
Churches & 6 & 1 \\
Museums and open air museusm & 3 & 1 \\
Others & 52 & 9 \\
\hline Total & 580 & 100 \\
\hline
\end{tabular}

Source: Sipetean (2010, p. 25)

The first street segment, for instance, has around 20 buildings at top seismic risk. As this was old, its infrastructure was precarious. Until the mid-1990s, there was no gas, unlike much of Bucharest. Similarly, as the water pipes were old and rusted, the pressure was low, prompting households to fall back on wells. Moreover, the pavement was in really bad shape. In terms of real estate dynamics, the 1990s were dominated by demolitions, mergers of land parcels, and the construction of new buildings.

The turning point in the gentrification of VLS was a short-lived project financed by Bucharest's $2^{\text {nd }}$ District in 2002. An early 1900s public transportation garage became redundant, as the transportation in Bucharest's inner ring is dominated by trams, subways, and trolley-buses. The local government decided to turn it into a shopping mall. To that end, the local government upgraded all the utility networks on VLS (water, sewerage, gas, the power grid, and the pavement). This had a major impact, transforming in the following years consumption, investment, and real estate in the area.

After this episode, the area acquired new consumption spaces, especially for food and drink. Whereas prior to 2002 the area's stores catered mainly to local needs, the pubs, restaurants and supermarkets now attract mainly outside clientele. Traditionally, Gemeni peasant market dominated the landscape of consumption, selling fresh produce, but also acting as a small cluster of services. After 2002, the main supermarket chain in Bucharest (MegaImage) constructed its only "concept store" right next to the peasant market. With 1600 square 


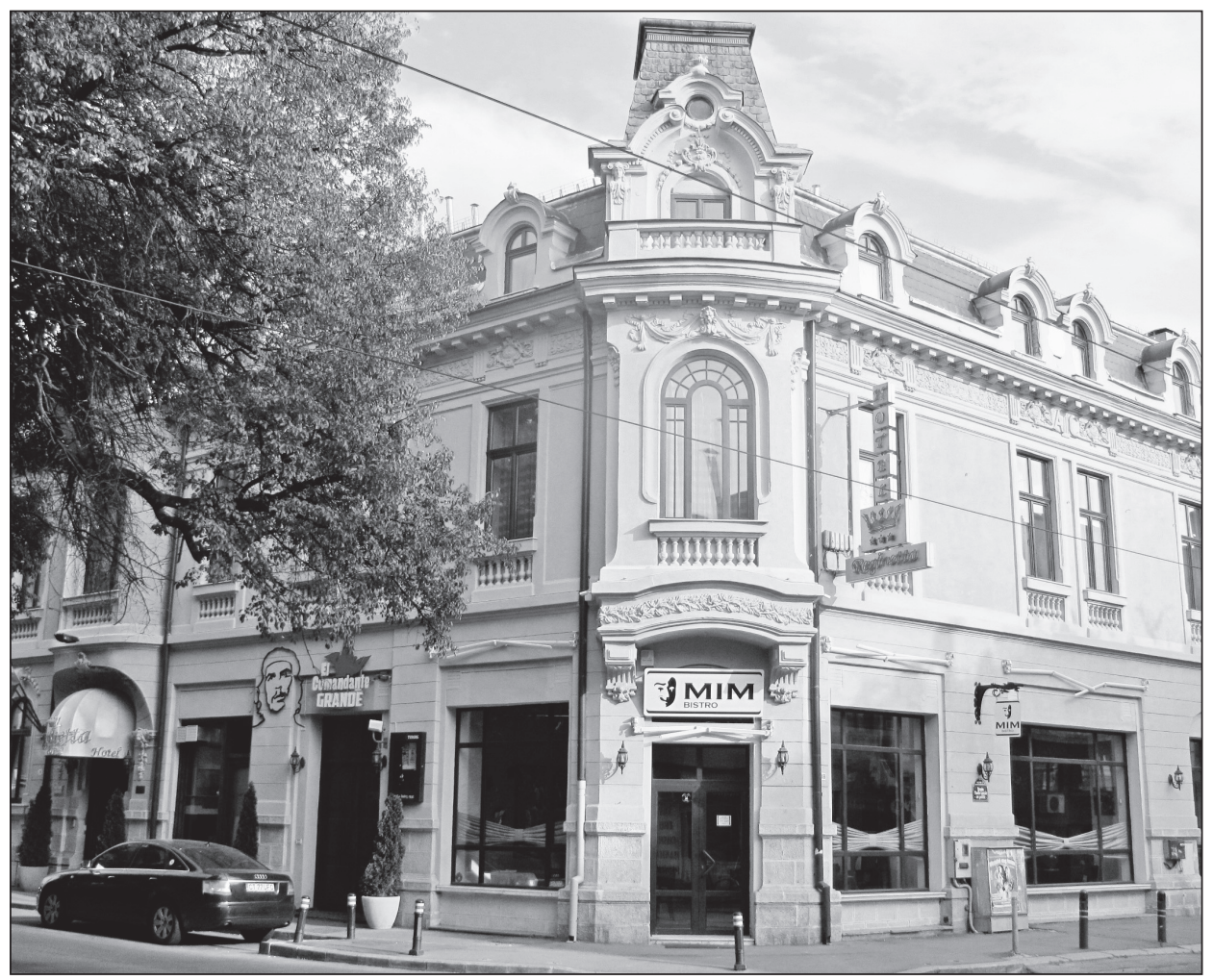

Fig. 3 - Mim bistro - ground floor and Hotel Reginetta - first floor, opened after the departure of state tenants

meters of retail space and parking, the concept store caters for consumers with "educated" tastes. It carries game, ingredients for Asian and Middle Eastern cuisine, a wide variety of cheeses, meat products and bread, French bakery products, "Romanian" bacon and cheese, exotic fruits and organic vegetables. There are also other new, more scattered spaces of consumption, such as 7 restaurants, 2 bistros, 3 bars, 2 dance clubs, 2 night clubs and massage parlors, 3 boutique hotels, 2 liquor stores, and 3 cultural centers, and a bookstore. In terms of built environment dynamics, many old buildings have been repaired and commercialized (see Fig. 3), and six condos have been finished.

Vasile Lascăr street is a good illustration of the transformation of consumption in the central and semi-central areas of the Bucharest. Overall, the area changed from a "God forsaken area" to a "has-it-all", diverse and dynamic one. Despite their relative decay and underinvestment in the 1970s and 1980s, the central areas have been attractive before, during, and after socialism, as they encompass the most valuable housing in Bucharest, administrative buildings, and cultural institutions. With different neighborhood effects and different intensities, and with the exception of the 1980s Stalinist "civic center" (Light, Young 2013), the trends presented above have transformed every neighborhood in this part of the city (Marin 2005, Simion 2010; Benedek 2006). 


\section{Conclusions}

In this article we have argued that the post-socialist transformation of property rights over housing - housing privatization, restitution, and subsequent commodification - has encouraged gentrification in Bucharest's central areas. The huge differences between "rent caps" (Bernt 2012) and market value created incentives for many actors to commodify such dwellings. This generated the voluntary and involuntary displacement of poorer families, and, later, forced evictions. Gentrification, in this context, was linked to capital formation, since the transactions of property rights and the displacement of the socialistera groups paved the way for real estate circulation as a way out of creating "capitalism without capitalists" (Eyal, Szelenyi, Townsley 1998).

One first research question was: who are the gentrifiers (and how do they operate)? We have identified six configurations of richer and poorer tenants, tenants turned owners, owners of nationalized apartments, marginal gentrifiers (Rose 1989), "political capitalists" (Staniszkis 1991), and supertenants (Verdery 2003). Their variety increased after 2002-2003, when international real estate investments flooding the city created residentialization and third-wave gentrification (Davidson, Lees 2005; van Gent 2012). These findings increase our knowledge of gentrification in East Central European cities. According to a survey of studies of three post-socialist cities (Sýkora 2005), gentrifiers tend to be the expats (in Prague), local yuppies (in Tallin), young middle-class families with children (in Budapest), students (several cities - see Haase et al. 2012), or affluent individuals rather than corporate developers in early gentrifying Moscow (Golubchikov, Badyina 2007, p. 7). Gentrifiers in Bucharest, prior to the real estate boom of the mid-2000s, were distinctively local and their trajectories were linked to socialist and post-socialist connections rather than international dynamics.

Our second research question was: how do gentrifiers change central city neighborhoods? In terms of investments, we noticed that in the $2000 \mathrm{~s}, 70 \%$ of all construction permits were for extensions, repairs, and improvements. Newbuilt gentrification generated high residential condos. Household composition between the 1992 and 2011 censuses indicated that gentrification is part of an overall scheme of metropolitan shifts and "multiple transformations" (Sýkora, Bouzarovski 2012) in Bucharest. These include: tertizarization, population aging, increased educational stock, smaller densities, and diminishing occupancy. The central areas, on the other hand, have shown a higher speed of change with a significant increase in the number of educated persons, larger apartments, and a reduced occupancy rate in rooms and apartments. Relative to the rest of the city, the population is getting younger: the age gap of the 1990s has almost closed, with significant gains in the number of young adults and decreases in that of senior citizens. In terms of cultural attractiveness, we have identified a booming entertainment scene in the historical center and a significant growth of leisure spaces in several neighborhoods. We have also found out that gentrification in Bucharest has had a patchy character, sometimes even within the confines of one building, a finding that reinforces Sýkora's point (2005, p 97) that "gentrifying places are characterized by a mixture of original population and gentrifiers, old and new establishments, refurbished and not-yet-renovated properties" (see also Smith 1986, p. 16; Marcuse 1986; 
Zukin 1987, p. 132). Since the privatization and restitution of housing were decentralized to a large number of beneficiaries, capital formation and the geographies of gentrification have also had a capillary character.

We close with three methodological remarks. One concerns the decadesold debate on the production side and cultural explanations of gentrification. The give-away privatization of valuable housing makes the assumptions of the rent gap and production side approach especially useful for understanding gentrification in post-socialist cities (Smith 1986, Smith 1996) - the more so since central areas have always been attractive in Central and East European cities before, during, and after socialism (see Hasse et al 2012; also Sýkora 2005, p. 100), thus making "cultural" explanations, as gentrification theory would have it, slightly less of a variable in this geographic context. Limited commodification stabilized the function, form, and to some extent the social composition of the centrally located areas. Limits on commodification have throughout the 1990s and early 2000s prevented the creation of a "frontier of profitability" (Bernt, Holm 2005, p. 114) in Bucharest, but tenants, landlords and real estate agents found ways to circumvent the regulations.

The second methodological note is a critique of the work carried out by gentrification researchers in general, including ourselves. One common shortcoming of gentrification research is that there is little to no focus on the displaced (Newman, Wyly 2006). Where do they go? How do they adjust? Although we have indicated some elements related to "voluntary" relocation, this remains under-researched; we fallen short of understanding linkages between gentrification, segregation, and substandard, shanty town living. In Bucharest, as in many European cities, gentrification "is actually desired and sought after by public authorities" (Pattaroni et al. 2012, p. 1225). According to one researcher and activist who studies social housing and evictions in Bucharest, the local administration actively avoids engaging with this issue. It directs the evicted towards remote and vague solutions - for instance, attending "work reconversion" programs - rather than offering them emergency assistance (Zamfirescu 2015). In several post-socialist cities there are conservative, anti-poor overtones that seem stronger than those in the "revanchist city" (Smith 1996) in the US (Duijzings 2010, p. 109; He 2007, p. 174; O'Neill 2014; Sýkora 2005, p. 94), thus making this issue a timely one.

Despite occasional controversies, there seems to be an agreement that "it is about time to end the debate over whether there is post-socialist gentrification" (Nagy, Timár 2012, p. 122). During the decades of the 1990s and 2000s, gentrification was documented in various former state socialist cities (see Jakóbczyk-Gryszkiewicz, Marcińczak, Wolaniuk 2014 for a review). Although we agree that we should leave behind the fall of socialism and link urban restructuring to globalization, gentrification research still needs to trace local forms, political configurations, and (post)socialist causes of gentrification. This is important so as to avoid universalizing the experience of global cities and thus represent other forms of gentrification as "variations" (Atkinson, Bridge 2005; Lees, Shin, Lopez-Morales 2015). To that end, we have pointed out the importance of property rights transformations in elucidating gentrification. This is often taken for granted in many studies, as if rent, land and housing markets are simply "out-here", rather than created by policies. Possible elements of a 
larger agenda relating gentrification and property rights include links between home ownership and the speed of gentrification (Show in Atkinson, Bridge 2005, p. 179), the importance of ownership of urban land for social housing development (Atkinson, Bridge 2005, p. 11), and the bypassing of cooperative and condo regulations in New York City (Smith, Defilippis 1999, p. 648).

\section{References:}

ATKINSON, R., BRIDGE, G., eds. (2005): Gentrification in a Global Context. Routledge, London, $308 \mathrm{pp}$.

BENEDEK, J. (2006): Urban Policy and Urbanization in the Transition Romania. Romanian Review of Regional Studies, 2, No. 2, pp. 51-64.

BERESCU, C. (2011): The Rise of the New European Roma Ghettos. Urban Research and Practice, 4, No. 3, pp. 344-352.

BERNT, M. (2012): The "Double Movements" of Neighborhood Change: Gentrification and Public Policy in Harlem and Prenzlauer Berg. Urban Studies, 49, No. 14, pp. 3045-3062.

BERNT, M., HOLM, A. (2005): Exploring the Substance and Style of Gentrification: Berlin's "Prenzlberg". In: Atkinson, R., Bridge, G. (eds.): Gentrification in a Global Context: The New Urban Colonialism. Routledge, London, pp. 107-122.

BODNAR, J. (1996): He that Hath to Him Should Be Given: Housing Privatization in Budapest after State Socialism. International Journal of Urban and Regional Research, 20, No. 4, pp. 616-636.

BORÉN, T., GENTILE, M. (2007): Metropolitan Processes in Post-Communist States: An Introduction. Geografiska Annaler B, 89, No. 2, pp. 95-110.

BROWN-SARACINO, J. (2010): The Gentrification Debates. Routledge, London, 382 pp.

CHELCEA, L. (2006): Gentrification, Property Rights and Post-socialist Primitive Accumulation (Bucharest, Romania). In: György, E., Kovács, Z. (eds.): Social Changes and Social Sustainability in Historical Urban Centres. CRS-HAS, Pecs, pp. 127-126.

CHELCEA, L. (2012): The "Housing Question" and the State-Socialist Answer. International Journal of Urban and Regional Research, 36, No. 2, pp. 281-296.

COLLIERS INTERNATIONAL (2012): Romania - Research \& Forecast Report: Mid-year 2012, http://www.colliers.com/ /media/Files/EMEA/Romania/research/Romania/2012-H1Romania-Research-Report.ashx (14.8.2013).

DANIELL, J., STRUYK, R. (1994): Housing Privatization in Moscow? International Journal of Urban and Regional Research, 18, No. 3, pp. 510-525.

DAVIDSON, M., LEES, L. (2005): New-built "gentrification" and London's Riverside Rennnisance. Environment and Planning A, 37, pp. 1165-1190.

DAWIDSON, K. (2004): Conflicts of Interest in the Restitution and Privatization of Housing since the Fall of Socialism. Europe-Asia Studies, 56, No. 1, pp. 119-141.

DUIJZINGS, G. (2010): From Bongo Bongo to Bosnia via the Balkans. In: Bohn T., Calic, M., J. (eds.): Urbanisierung und Stadtentwicklung in Südoesteuropa vom 19. bis zum 21. Jahrhundert, 47. Otto Sagner, München, pp. 93-132.

EYAL, G., SZELENYI, I., TOWNSLEY, E. (1998): Making Capitalism without Capitalists. Verso, London, $333 \mathrm{pp}$.

FORREST, R., MURIE, A. (1995): From Privatization to Commodification. International Journal of Urban and Regional Research, 19, No. 3, pp. 407-422.

GENTILE, M., TAMMARU, T., VAN KEMPEN, R. (2012): Heteropolitanization: Social and Spatial Change in Central and Eastern Europe. Cities, 29, No. 5, pp. 291-350.

GOLUBCHIKOV, O., BADYINA, A. (2007): Conquering the Inner-City: Urban Redevelopment and Gentrification in Moscow. In: Tsenkova, S., Nedovic-Budic, Z. (eds.): The Urban Mosaic of Post-Socialist Europe. Physica-Verlag, Heidelberg, pp. 195-212.

HAASE, A., KABISCH, S., GROSSMAN, K., STEINFÜHRER, A., HALL, R. (2012): Residential Change and Demographic Challenge: The Inner City of East Central European in the $21^{\text {st }}$ Century. Ashgate, London, $380 \mathrm{pp}$. 
HACKWORTH, J., SMITH, N. (2001): The changing state of gentrification. Tijdschrift for Economische en Sociale Geographie, 92, No. 4, pp. 464-477.

HE, S. (2007): State-sponsored Gentrification under Market Transition: The case of Shanghai. Urban Affairs Review, 43, No. 2, pp. 171-198.

HELLER, M. (1998): The Tragedy of Anticommons: Property in the Transition from Marx to Markets. Harvard Law Review, 111, No. 3, pp. 622-688.

JAKÓBCZYK-GRYSZKIEWICZ, J., MARCIŃCZAK, S., WOLANIUK, A. (2014): Gentrification Process in the City. In: Marszał, T. (ed.): Society and Space in Contemporary Poland in Łódź. Łódź University Geographical Research, pp. 83-111.

KOVÁCS, Z. (1994): A City at the Crossroads: Social and Economic Transformation In Budapest. Urban Studies, 31, No. 7, pp. 1081-1096.

KOVACS, Z. (2013): Urban Renewal in the Inner City of Budapest: Gentrification from a Postsocialist Perspective. Urban Studies, 50, No. 1, pp. 22-38.

LEES, L., SHIN H.B., LOPEZ-MORALES, E. (2015): Global Gentrifications. Policy Press, Bristol, $416 \mathrm{pp}$.

LIGHT, D., YOUNG, C. (2013): Urban Space, Political Identity and the Unwanted Legacies of State Socialism. Nationalities Paper, 41, No. 4, pp. 515-535.

MANDIC, S. (2012): Home Ownership in Post-socialist Countries. In: Ronald, R. (ed.): Beyond Homeownership. Routledge, London.

MARCIŃCZAK, S. (2012): The evolution of spatial patterns of residential segregation in Central European Cities. Cities, 2, No. 5, pp. 300-309.

MARCIŃCZAK, S., MUSTERD, S., STEPNIAK, M. (2012): Where the grass is greener: social segregation in three major Polish cities at the beginning of the $21^{\text {st }}$ century. European Urban and Regional Studies, 19, No. 4, pp. 383-403.

MARCIŃCZAK, S. et al., (2014): Urban geographies of hesitant transition: Tracing socioeconomic segregation in post-Ceausescu Bucharest. International Journal of Urban and Regional Research, 38, No. 4, pp. 1399-1417.

MARCUSE, P. (1986): Abandonment, Gentrification, and Displacement. In: Smith, N., Williams, P. (eds.): Gentrification of the City. Allen and Unwin, Boston, pp. 153-177.

MARIN, V. (2005): Inhabiting the "Old" Socialist Housing Estates versus "New" Capitalist Suburbia. In: Eckardt, F., Hassenpflug, D. (eds.): Paths of Urban Transformation. Peter Lang, Frankfurt am Main, pp. 121-141.

NAGY, E., TIMÁR, J. (2012): Urban Restructuring in the Grip of Capital and Politics: Gentrification in East-Central Europe. In: Csapó T., Balogh, A. (eds.): Development of the Settlement Network in the Central European Countries. Springer, Heidelberg, pp. 121-135.

NEWMAN, K., WYLY, E. (2006): The Right to Stay Put, Revisited. Urban Studies, 43, No. 1, pp. 23-57.

O'NEILL, B. (2014): Cast Aside: Boredom, Downward Mobility, and Homelessness in Postcommunist Bucharest. Cultural Anthropology, 29, No. 1, pp. 8-31.

PATTARONI, L. et al. (2012): The Dynamics of Multifaceted Gentrification. International Journal of Urban and Regional Research, 36, No. 6, pp. 1223-1241.

PICKVANCE, C. (1994): Housing Privatization and Housing Protest in the Transition from State Socialism. International Journal of Urban and Regional Research, 18, No. 3, pp. 433-450.

PICKVANCE, C. (2002): State Socialism, Post-Socialism and Their Urban Patterns. In: Eade J., Mele, C. (eds): Understanding the City. Blackwell, Oxford, pp. 183-203.

RONALD, R., ELSING, M., eds. (2012): Beyond Home Ownership. Routledge, London, 230 pp.

ROSE, D. (1989): A Feminist Perspective of Employment Restructuring and Gentrification: The Case of Montréal. In: Wolch, J., Dear, M. (eds.): The Power of Geography. Routledge, London, pp. 118-138.

RUFAT, S. (2011): Transition post-socialiste et vulnerabillité urbaine à Bucarest. Editura Universității din Bucureşti, Bucureşti, 312 pp.

RUOPPILA, S. (2004): Processes of Residential Differentiation in Socialist Cities. European Journal of Spatial Development, 9, pp. 2-24.

SIMION, G. (2010): The Spatial Changes of Land Use in the Bucharest Metropolitan Area 1970s-2000s. Human Geographies, 4, No. 2, pp. 115-123. 
SIPETEAN, A. (2010): The Transformation of Lipsacani Area. MA dissertation, Department of Sociology, University of Bucharest, $35 \mathrm{pp}$.

SMITH, N. (1986): Alternatives to Orthodoxy. In: Smith, N., Williams, P. (eds.): Gentrification of the City. Allen and Unwin, Boston, $250 \mathrm{pp}$.

SMITH, N. (1996): The New Urban Frontier: Gentrification and the Revanchist City. Routledge, London, $267 \mathrm{pp}$.

SMITH, N. (2002): New Globalism, New Urbanism. Antipode, 34, No. 3, pp. 427-450.

SMITH, N., DEFILIPPIS, J. (1999): The Reassertion of Economics: 1990s Gentrification in the Lower East Side. International Journal of Urban and Regional Research, 23, No. 4, pp. 638-653.

SOAITĂ, A. (2012): Strategies for In Situ Home Improvement in Romanian Large Housing Estates. Housing Studies, 27, No. 2, pp. 1008-1030.

SOAITĂ, A. (2013): Romanian Suburban Housing. Urban Studies, 50, No. 10, pp. 2084-2101.

STAN L. (2013): Reckoning with the Communist Past in Romania. Europe-Asia Studies, 65, No. 1, pp. 127-146.

STANISZKIS, J. (1991): "Political Capitalism" in Poland. East European Politics and Society, 5, pp. 127-141.

STOICA, C.A. (2004): From Good Communists to Even Better Capitalists? East European Politics and Societies, 18, No. 2, pp. 236-277.

STRUYK, R. (1996): Economic Restructuring of the Former Soviet Bloc: The Case of Housing. Urban Institute Press, Washington, $375 \mathrm{pp}$.

SÝKORA, L. (2005): Gentrification in post-communist cities. In: Atkinson, R, Bridge, G. (eds): Gentrification in a Global Context. Routledge, London, pp. 91-105.

SÝKORA, L., BOUZAROVSKI, S. (2012): Multiple Transformations. Urban Studies, 49, No. 1, pp. 43-60.

TOTELECAN, S. (2015): Eating out: (Re)searching the labs of social(bi)lity. An. Inst. De Ist. "G. Barițiu" din Cluj-Napoca, Seria Humanistica, 13, pp. 7-28.

TUDORA, I., CULESCU, M. (2011): Looking down on or Looking up to Bucharest's Public Spaces, http://www.rpr.ro/index.php/pub2011/cities-methodologies (12. 8. 2013).

URSE, D, POPESCU, R. (2009): Politici familiale şi de gen în Romania. Alpha MDN, Bucureşti, $72 \mathrm{pp}$.

WYLY, E., K., HAMMEL, D. (2003): Mapping Neo-Liberal American Urbanism. In: Atkinson, R., Bridge, G. (eds.): Gentrification in a Global Context. Routledge, London, pp. 18-57.

VAN GENT, W.P.C. (2012): Neoliberalization, Housing Institutions and Variegated Gentrification: How the "Third Wave" Broke in Amsterdam. International Journal of Urban and Regional Research, 37, No. 2, pp. 503-522.

VERDERY, K. (2003): The Vanishing Hectare. Cornell University Press, Ithaca, 427 pp.

ZAMFIRESCU, I. (2015): Housing Evictions, Displacement and the Missing Social. Calitatea Vieții, 26, No. 4, forthcoming.

ZUKIN, S. (1982): Loft living as "historical compromise" in the urban core: The New York Experience. International Journal of Urban and Regional Research, 6, No. 2, pp. 256-276.

ZUKIN, S. (1987): Gentrification. Annual Review of Sociology, 13, pp. 129-147.

\section{Shrnutí}

\section{KDO JSOU AKTÉŘI GENTRIFIKACE A JAK OVLIVŇUJÍ ÚZEMÍ VNITŘNÍHO MĚSTA? PRIVATIZACE, KOMODIFIKACE A GENTRIFIKACE V BUKUREŠTI}

Cílem článku je rozšířit naše chápání gentrifikace mimo tradiční rámec anglosaských zemí tím, že se zaměří na její působení v post-socialistických městech. V duchu dosavadní výzkumné tradice si klademe hlavně dvě otázky: (1) kdo jsou aktéři gentrifikace (a jak operují) v post-socialistickém prostředí? a (2) jaké jsou souhrnné sociální a prostorové dopady jejich působení? Při odpovědích na tyto otázky zdůrazňujeme hlavně význam změn v oblasti vlastnického práva na proces gentrifikace. Devadesátá léta, stejně jako první desetiletí nového 
století, bylo obdobím výrazné reformy vlastnických práv, změny státního zřízení a využívání levné pracovní síly v celém regionu. Naše studie přichází s novou typologií strategií komodifikace nemovitostí, v niž je gentrifikace úzce navázaná na změny ve vlastnických právech nemovitostí. Tato typologie byla vytvořena na základě několika existujících studií gentrifikace, bytové situace a lokálních změn v post-socialistických městech.

Při analýze gentrifikace jsme využili kombinovanou metodologii. Výzkum se soustředil na prostor centrálních částí Bukurešti, které leží v prstenci vnitřního města. Ten zaujímá přibližně 20 procent celkové rozlohy města a dominuje mu převážně nižší výstavba. Abychom nalezli odpověd na první otázku, provedli jsme 41 rozhovorů s obchodníky s realitami, bývalými majiteli nemovitostí a současnými nájemníky. Déle jsme se rozhodli pro zúčastněná pozorování pomocí prohlídek vedených některými z realitních obchodníků i nezúčastněná pozorování v průběhu terénního výzkumu. Část komunikace probíhala formálně, prostřednictvím polostrukturovaných rozhovorů, jindy zahrnovala spíše neformální konverzaci ve zkoumaných lokalitách.

Abychom mohli zodpovědět druhou výzkumnou otázku, rozhodli jsme se využít kombinaci primárně kvantitativních, ale i kvalitativních technik. Data byla analyzována z hlediska tř́ klíčových komponent: investice, složení domácnosti, kulturní atraktivita. Pro zkoumání realitních investic jsme sestavili databázi stavebních povolení vydaných pro zkoumanou oblast v období 1990-2012. Složení domácností jsme vyhodnotili za pomoci deskriptivní statistiky a dat ze sčítání za roky 1992, 2002 a 2011. Kulturní atraktivitu jsme hodnotili na základě terénních pozorování a sekundárních informací o zábavních a gastronomických službách v oblasti. Slučování relativně velkých městských územních celků příliš neumožňuje zachytit specifickou povahu lokální gentrifikace jednotlivých obytných zón. Proto jsme se rozhodli analýzu doplnit o dvě případové studie malých obytných oblastí, které nám pomohly lépe odhalit nepravidelnou povahu městské gentrifikace.

V rámci odpovědi na první otázku jsme identifikovali šest konfigurací bohatších a chudších nájemníků, nájemníky, z nichž se stali majitelé, majitele znárodněných bytů, marginální agenty gentrifikace, „politické kapitalisty“ a „supernájemníky“. Tato různorodost se ještě zvětšila po roce 2002/3, kdy začal na trh s realitami mocně proudit zahraniční kapitál a způsobil tzv. gentrifikaci třetí vlny. Tyto výsledky zvyšují naše povědomí o gentrifikaci ve městech střední a východní Evropy. Z existujících studií post-socialistických se dozvídáme, že aktéry gentrifikace mohou být ve výrazné míře zahraniční občané (v Praze), místní mladí profesionálové (v Tallinnu), mladé rodiny střední třídy s dětmi (v Budapešti), studenti, či bohatí jednotlivci, spíše než developerské firmy jako v počátcích gentrifikace Moskvy. Před realitním boomem z poloviny prvního desetiletí nového století byli aktéri gentrifikace v Bukurešti velmi lokální povahy a jejich trajektorie byly silně navázané na socialistické a ranně post-socialistické konexe, spíše než na dynamiku mezinárodního prostředí.

Odpověd na druhou otázku vyzdvihuje především roli oprav a vylepšování existujících budov, nicméně je možné nalézt i zcela nové stavby, především kondominia postavená na místě zbořených původních budov po odsunutí předchozích obyvatel. Složení domácností mezi lety 1992 a 2011 poukazuje na to, že gentrifikace je součástí celkových změn v metropolitní oblasti Bukurešti. K těm se řadí také „terciarizace“, populační stárnutí, rostoucí míra vzdělanosti, menší hustota a klesající zaplněnost. Oblasti vnitřního města zažívají ještě rychlejší změny $\mathrm{s}$ ohledem na nárůst počtu vzdělaných osob a velikosti bytů a pokles zaplněnosti místností a bytů. Ve srovnání se zbytkem města populace vnitřního města relativně mládne - věková propast z roku 1990 se téměř uzavřela.

Závěrem je potřeba učinit tři poznámky $\mathrm{k}$ metodologii. Za obzvlášť užitečné považujeme přístupy zdůrazňující roli produkčních faktorů a význam rozdílu mezi potenciálním a skutečným výnosem z nemovitosti („rent gap“) pro pochopení gentrifikace v postsocialistických městech. To platí zejména proto, že vnitřní oblasti měst střední a východní Evropy byly atraktivní lokalitou také před i během období státního socialismu, a omezená míra komodifikace v devadesátých letech pomohla stabilizovat funkci, povahu a do jisté míry i sociální skladbu vnitroměstských zón.

Druhá poznámka se týká malého zájmu o vytlačované obyvatele v rámci studia gentrifikace. Kam odcházejí? Jak se se změnami vyrovnávají? Přestože jsme některé prvky spojené s „dobrovolnou“ relokací zmínili, toto téma si zaslouží větší pozornost. Zatím přiliš 
nerozumíme vazbám mezi gentrifikací, segregací a substandartním bydlením. V mnoha post- socialistických městech se objevují konzervativní, proti chudým nepřátelsky zaměřené kontury, ještě silnější než obdobné tlaky v „revanšistických městech“ Spojených států, což ještě podtrhává důležitost tohoto tématu.

Třetím bodem je, že studium gentrifikace by mohlo být obohaceno silnější diskuzí role vlastnických práv. Přestože pomalu nastává čas opustit pád socialismu jako styčné téma a spíše napojovat studium městské restrukturalizace na fenomén globalizace, stále existuje prostor pro vlivy lokálních forem a politických konfigurací či dalších (post)socialistických dimenzí gentrifikace. Tímto lze také lépe zabránit falešné univerzalizaci vývoje globálních měst a umožnit chápání různých forem gentrifikace jako jejích „variant“.

Obr. 1 - Mapa Bukurešti a studového území.

Obr. 2 -Letecký snímek okolí ulice Eminescu. D - zbořeno, C - kondominia, S - kondominia $\mathrm{z}$ dob socialismu.

Obr. 3-Mim bistro v přízemí a Hotel Reginetta v prvním patře, otevřené po odchodu nájemníků.

Authors' affiliation: University of Bucharest, Department of Sociology, Bucharest, Romania; e-mail:liviu.chelcea@sas.unibuc.ro,raluca.popescu@sas.unibuc.ro,darie.cristea@sas.unibuc.ro.

Initial submission, 2 July 2014; final acceptance 18 April 2015.

\section{Please cite this article as:}

CHELCEA, L., POPESCU, R., CRISTEA, D. (2015): Who Are the Gentrifiers and How Do They Change Central City Neighbourhoods? Privatization, Commodification, and Gentrification in Bucharest. Geografie, 120, No. 2, pp. 113-133. 